\section{Disability and human rights. For an ethic of non-indifference}

\section{Alessio Musio ${ }^{1}$}

${ }^{1}$ Università Cattolica del Sacro Cuore. Departamento de Filosofía, Centro di Ateneo di Bioetica.

Prof. Asociado de Filosofía Moral. Doctor en Bioética.

Recibido: 25-11-2017 Aprobado: 29-11-2017

Citar como: Musio A. Disbility and human rights. For an ethic of non-indifference. CASUS. 2017;2(3):135-138.
Today the subject of disability is, in fact, an unavoidable problem for the quality of social and health policies. If in one hand, there is widespread hospitalization of many phases of life, on the other, there is a constant global demand for assistance, inclusion, and participation perceived. At the same time, States are facing this situation from their different political systems and their uneven availability of funds.

In this scenario, a turning point - by its universal character was determined by the introduction of the International Classification of Functioning, Disability, and Health (ICF) as instrument wanted by WHO to classify the functioning (more than health) of individuals (1). Disability, according to this model, cannot be only considered as a matter subjected to the category of medical care but becomes also a social and political problem. In the logic of the "bio-psycho-social" model that the classification drives, in fact, disability is not given only by an specific health condition (product of a disease or impairment), but by the way in which that condition relates to the environment in which the subject is inserted, which can act as barrier or as a facilitator of its functioning.

The simplest example is the architectural barriers for a person who lives a motor disability, although it is likely that stigmatize over time. Since disability, in fact, is expressed in many ways. Therefore, it is inappropriate to refer to it with only this case in mind, thus forgetting the other forms of disability. Which, for example, cognitive and sensory, determine conditions of radical dependence. Therefore, dealing with motor disability does not mean only taking care of the needs and health problems (sometimes permanent) of that person, but recognizing the ethical and political duty to take measures to change the environment in which it is inserted. In this sense, the measures to be implemented transcend medicine and do not only deal with the subject. On the contrary, also concern all those who, perhaps without knowing it, share with that person that neighborhood, that building, that sidewalk and those stairs, and that, by their configuration, help to determine disability. 
As has been observed, however, is not only the "physical" environment to constitute a barrier or a facilitator of the functioning and the quality of life of people with disabilities (2). Often, the barriers are of a "cultural" nature and are related to the attitudes of people, politics, and governments. Similarly, with behaviors of those who actually are responsible for the care, education, and assistance. Indifference, disinterest, apathy, inability to change the way we "have always done things" represent the barriers that are prone to be even more insurmountable than material obstacles.

Is in this sense that the disability requires a radical ethic of nonindifference. In effect, this topic is dominated from the ethical-political point of view - as evidenced by Sen and Nussbaum (3) - by a purely quantitative logic. It interprets people with disabilities as a minority and special category of citizens to deal with, at most, only after having responded to the problems of the majority of the population. The above is given on the basis of an unacceptable and deeply unfair logic of postponement.

The introduction of the UN Convention on the Rights of Persons with Disabilities (4) implemented a radical paradigm shift: people with disabilities can no longer be considered as a separate category of citizens and their rights should not be considered as the rights of a minority (4). For the simple reason that there are not "disabled", but "people with disabilities". This change is based on an egalitarian logic that recalls how each man, due to a health problem and an unfavorable environment, can suddenly find himself, temporarily or permanently, in a condition of disability.

This paradigm's change has several implications. First, clarifies how the rights of persons with disabilities are no more than human rights. Which must be conceived, however, in a concrete way. That is, based on the different conditions of disability. Therefore, and this is the second aspect, it helps to understand how these rights are not respected. The achievement of social policies, health, education and support interventions that do not take into account that they are human rights, or do so in a partial degree, thus carry out inhuman attitudes or policies.

There is not enough reflection on the importance of this document that all democratic states are called to respect - has established the ethical and political task of governments and institutions to eliminate or reduce the degree of disability of people. This statement, in fact, has a fundamental bioethical significance: not only because it condemns all forms of indifference, but because it automatically excludes the eugenic and suppressive practices of persons with disabilities. Since disability is a relationship, so it is never simply assimilable to someone's existence.

In this way, it is recognized how the dignity of people with disabilities trivially depends on being a human person, and descends from the mere fact of existing, of being generated. Adriano Pessina has called this logic the "ethics of the despite". Which, at the same time, recognizes both the fundamental value of every son of man "in spite of" the 
presence of these forms of illness or disability that tend to obscure more or less some relevant capacities, as an obligation of society to intervene to try to reduce the causes that lead to the spread of disability (5).

Despite some uncertainty, for example, when the Convention in its third article emphasizes the meaning of disability as an expression of human difference, disregarding the logic of equality that animates it (4). However, the UN Convention reaffirms a fundamental assumption (4). Namely, the fact that a man does not have to do anything to acquire or merit his human dignity. It must be recognized simply. Even when it is not able to claim it as it happens in many situations of disability. Often these people are not considered at the level of human dignity. This conception is a true vehicle of ethical indifference. In it, the value of a man is considered as something that must be acquired on the basis of his ability to make a contribution to society. This logic prevents the recognition of human dignity and excludes the possibility of the true equality that human rights seek to express.

The way of thinking and dealing with the complex problems of disability becomes a matter of justice. In other words, a task in which to measure the human quality of a society. It is in accordance with this awareness that this issue of the Journal intends to offer its readers a wide range of reflections on disability. The articles take into account their different forms, considering the diverse stages of life in which it is developed and paying attention to environmental factors (related to poverty, social exclusion, lack of education, training and inefficiency of the health system, etc.) that contribute to the density of this problem.

However, one aspect remains to be clarified. Thinking in ethical terms about disability issues means putting into question many of the categories that are now taken for granted in the so-called theories of justice. Which are based on an abstract myth of citizen characterized by being male, adult, healthy, independent and totally cooperative. Martha Nussbaum states that these theories about justice lead us to think that our essential core is to be self-sufficient, forgetting that the normal cycle of human life begins with a period of extreme dependence in which our functioning is similar to that of people who are mentally or physically disadvantaged throughout their lives (3). That is why we must reaffirm - and it is the objective of this edition of the Journal - that this abstract model of citizen is not only false but also becomes the prerequisite of policies, decisions and deficient actions at the ethical level.

To speak of disability as an intrinsic possibility of the human condition means, then, to radically revise our image of human being, to understand and exploit that dependence. As well as, give value to the need for attention and help that characterizes us in different ways, but permanently as human beings. If it is true that "being human means being a son", this leads us to learn that these needs express the essence of each one of us and that, in this respect, no indifference will ever be justified. 


\section{BIBLIOGRAPHIC REFERENCES}

1. World Health Organization, International Classification of Functioning, Disability and Health. Geneva: WHO; 2001.

2. Pessina A. Paradoxa. Etica della condizione umana. Milano: Vita e Pensiero; 2010.

3. Nussbaum M. Giustizia sociale e dignità umana: Da individui a persone. Bologna: Il Mulino; 2002.

4. Convention on the Rights of Persons with Disabilities. NY; 13 de diciembre de 2006. New York: United Nations; 2006.

5. Pessina A. Venire al mondo. Riflessione filosofica sull'uomo come figlio e come persona. In: Cariboni C, Oliva G, Pessina A, editores. Il mio amore fragile. Storia di Francesco. Arona: XY.IT Editore; 2011. p. 63-93. 